\title{
IN 718 の疲労き裂伝ぱ機構に及ぼす清浄度の影響*
}

\author{
傳 田岳 史*1, 菊 地祐 久*2 \\ 寺 本 徳 郎*3, 斉 藤 正 克 ${ }^{* 3}$
}

\section{Effect of Cleanliness on Fatigue Crack Growth Mechanism of IN 718}

\author{
Takeshi DENDA, Hirohisa KIKUCHI, \\ Tokuo TERAMOTO and Masakatsu SAITO
}

\begin{abstract}
It is widely understood that the fatigue life of nickel-base superalloys is greatly increased as a consequence of the inclusion elimination in the melting process. Electron beam cold hearth remelting is a recently developed technique that offers the most dramatic improvements in the cleanliness of superalloys. However, the relation between fatigue characteristics and cleanliness has not been well investigated. In this work, fatigue crack growth rate tests were conducted at ambient temperature on commercial grade IN 718 and electron beam melted clean IN 718. The fatigue crack growth rate test shows that small surface cracks in the clean materials propagate considerably slower than those in the conventionally processed materials. In contrast to the behavior of small cracks, long through cracks propagate faster in the clean materials than in the conventionally processed materials. Since the small crack initiation and propagation period is the major portion of the fatigue life, the behavior of small cracks has a more important effect on the fatigue life than the behavior of long cracks.
\end{abstract}

Key Words : IN 718, Cleanliness, Small Surface Crack, Fatigue Crack Growth Rate, Inclusion, Grain Size

\section{1. 緒言}

ニッケル基合金の疲労寿命は，合金の清浄度に大き く影響されることが知られている。近年, 高清浄度溶 解技術の進歩により, 疲労き裂の起点となる欠陥, 特 に非金属介在物の量と大きさを制御して, 疲労寿命を 格段に長くすることが可能となってきている. 電子ビ ームコールドハース溶解法(EBCHR: Electron Beam Cold Hearth Remelting) はニッケル基合金中 の非金属介在物を除去する最新のプロセスであり(1), ジェットエンジンの回転部品用ニッケル基合金の製造 等に応用が始められている(2). しかし, 製品の安全性 を確保し，寿命を正しく予測するためには，微小な欠 陥等から発生した疲労き裂が伝ぱし，大きなき裂へと 成長して破壊に至るまでのき裂伝ぱ機構を統合的に把 握する必要がある、ニッケル基合金の疲労き裂伝ば機 構に関して，介在物の影響を積極的に取扱った例はほ とんどなく，定量的に評価されたニッケル基合金の

* 平成 6 年 3 月 29 日 ·第 71 期通常総会講演会において講演, 原稿受付 平成 6 年 3 月 29 日.

*1 正員, (株) ジャパンエナジー（®105 東京都港区虎)門 210-1).

*2 学生員, 筑波大学大学院 (画305 つくば市天王台 1-1-1).

$* 3$ 正員, 筑波大学構造工学系.
「清浄度」と, き裂伝ぱ機構との関連性を調べた研究は 見当たらない. 本研究では, 電子ビームボタン溶解法 により清浄度を分析した 4 種類の IN 718 の, 長い貫 通き裂の疲労き裂伝ぱ試験および表面微小疲労き裂発 生伝ぱ試験を室温で行い, 清浄度の影響を検討した。 前報 ${ }^{(3)}$ で示したように IN 718 の疲労き裂伝ぱ特性は 結晶粒径の影響を受ける。粗い結晶粒の材料と細かい 結晶粒の材料とで清浄度の影響を調べるため, 4 種類 の供試材料のうち, 2 種類は粗結晶粒で清浄度の高い ものと低いもの, 他の 2 種類は細結晶粒で清浄度の高 いものと低いものとした。

\section{2. 供 試 材 料}

供試材料は, 真空誘導溶解により溶製し, 鍛造した, 粗結晶粒のもの (CG-VIM), 真空誘導溶解の後に真空 アーク溶解により再溶解し, 鍛造した細結晶粒のもの (FG-VAR), 真空誘導溶解の後に電子ビームコール ドハース溶解し, 鍛造した粗結晶粒のもの(CG-EB) および細結晶粒のもの (FB-EB)の 4 種である.

粗結晶粒材には, 下記の条件により溶体化処理およ び時効処理を施した。

溶体化処理 : $980^{\circ} \mathrm{C} \times 1 \mathrm{~h} \rightarrow$ Air Coll

時効処理 $: 720^{\circ} \mathrm{C} \times 8 \mathrm{~h}$ 
表 1 供試材の化学成分 [wt.\%]

\begin{tabular}{|c|c|c|c|c|c|c|c|c|c|c|c|c|c|c|c|c|c|c|}
\hline & C & $\mathbf{P}$ & $S$ & $\mathrm{Nb}$ & $\mathrm{Ti}$ & $\mathrm{Al}$ & $\mathrm{Mn}$ & $\mathrm{Fe}$ & $\mathrm{Co}$ & Mo & $\mathrm{Cr}$ & $\mathrm{Cu}$ & $\mathrm{Si}$ & $\mathrm{Mg}$ & $\mathrm{Ni}$ & $\mathrm{B}$ & o & $\mathrm{N}$ \\
\hline FG-VAR & 0.040 & 0.003 & 0.0005 & 5.38 & 0.98 & 0.60 & 0.09 & 18.89 & 0.15 & 2.88 & 18.13 & 0.07 & 0.11 & 0.0009 & 52.29 & 0.005 & 0.0005 & 0.0063 \\
\hline CG-EB & 0.048 & 0.001 & 0.0019 & 4.86 & 0.90 & 0.55 & 0.01 & 18.64 & 0.20 & 3.02 & 19.38 & 0.02 & 0.09 & 0.0002 & 52.29 & 0.004 & 0.0005 & 0.0024 \\
\hline FG-EB & 0.031 & 0.001 & 0.0007 & 5.30 & 1.02 & 0.50 & 0.012 & 18.53 & 0.35 & 3.01 & 17.91 & 0.08 & 0.12 & 0.0002 & 53.10 & 0.004 & 0.0005 & 0.0030 \\
\hline
\end{tabular}

表 2 供試材の機械的性質

\begin{tabular}{|l|c|c|c|c|c|}
\hline & $\begin{array}{c}\text { ASTM } \\
\text { G.S. No. }\end{array}$ & $\begin{array}{c}\text { Ave. Grain } \\
\text { Size }(\mu \mathrm{m})\end{array}$ & $\begin{array}{c}0.2 \% \text { PS } \\
(\mathrm{MPa})\end{array}$ & $\begin{array}{c}\text { UTS } \\
(\mathrm{MPa})\end{array}$ & $\begin{array}{c}\text { Elong. } \\
(\%)\end{array}$ \\
\hline OG-VIM & 5 & 65 & 1105 & 1284 & 18 \\
\hline FG-VAR & 10 & 11 & 1195 & 1435 & 12 \\
\hline CG-EB & 6 & 45 & 1107 & 1321 & 16 \\
\hline FG-EB & 10 & 11 & 1131 & 1480 & 8 \\
\hline
\end{tabular}

Furnace Cool to $620^{\circ} \mathrm{C}$ at $55^{\circ} \mathrm{C} / \mathrm{h}$

$$
620^{\circ} \mathrm{C} \times 8 \mathrm{~h} \rightarrow \text { Air } \mathrm{Cool}
$$

細結昆粒材には，細かい粒径を維持するため，下記 の Direct Aging Processにより時効処理を施した。 時效処理 $: 720^{\circ} \mathrm{C} \times 8 \mathrm{~h}$

Furnace Cool to $620^{\circ} \mathrm{C}$ at $55^{\circ} \mathrm{C} / \mathrm{h}$

$$
620^{\circ} \mathrm{C} \times 8 \mathrm{~h} \rightarrow \text { Air Cool }
$$

表 1 にそれぞれの材料の化学成分を示す．表 2 に機 械的性質を示寸.

ニッケル基会金の清浄度評価方法としては，電子ビ ーンボタン溶解法(4) による非金属介在物分析が広く 行われている.これは, 電子ビームにより $1 \mathrm{~kg}$ 程度の 供試材を真空中で半球形の水冷銅鋳型に溶かし落と し，溶体を保持する間に低比重の非金属介在物を浮上 させ，凝固後に，浮上した非金属介在物粒子の数と大 きさの測定および化学成分分析を行うものである. 本 研究では, Leybold 社製 ES-1-60 形電子ビームボ夕 ン溶解装置を用いてボタンサンプルの溶解を行い, 日 本電子製 JCMA 733 形 EPMA 装置を用いて非金属介 在物粒子の計量拉よび化学成分分析を行った，結果を 表 3 に示す.すべての材料で主たる介在物は $\mathrm{Al}_{2} \mathrm{O}_{3}$ で あった。窒素濃度の高い FG-VAR 材ではこのほかに $\mathrm{TiN}$ が多く検出された。 $2 \mu \mathrm{m}$ よりも小さい介在物は, 結晶粒径, $\mathrm{NbC}$ に代表される粒界に析出した炭化物 に対して十分に小さく，有害なものとはみなされない ため ${ }^{(5)}, 2 \mu \mathrm{m}$ 以上の粒子の計量を行った.

電子ビームコールドハース溶解された材料は, 従来
表 3 電子ビームボタン溶解法による非金属介在物分析

\begin{tabular}{|l|c|c|c|l|}
\hline & $\begin{array}{l}\text { Inclusions/kg } \\
\geq 2 \mu \mathrm{m}\end{array}$ & $\begin{array}{c}\text { Inclusions/kg } \\
\geqq 25 \mu \mathrm{m}\end{array}$ & $\begin{array}{c}\text { Largest } \\
\text { Particle } \mu \mathrm{m}\end{array}$ & $\begin{array}{c}\text { Major } \\
\text { Inclusions }\end{array}$ \\
\hline CG-VIM & $\approx 5000$ & $\approx 1000$ & 380 & $\mathrm{Al}_{2} \mathrm{O}_{3}$ \\
\hline FG-VAR & $\approx 10000$ & $\approx 1000$ & 340 & $\mathrm{TiN} \mathrm{Al}_{2} \mathrm{O}_{3}$ \\
\hline CG-EB & 105 & 24 & 45 & $\mathrm{Al}_{2} \mathrm{O}_{3}$ \\
\hline FG-EB & 50 & 4 & 35 & $\mathrm{Al}_{2} \mathrm{O}_{3}$ \\
\hline
\end{tabular}

表 4 介在物粒子間の平均距離

\begin{tabular}{|c|c|c|c|c|}
\hline & OG-VIM & FG-VAR & CG-EB & FG-EB \\
\hline $\begin{array}{c}\text { Inter-Inclusion } \\
\text { Distance }(\mu \mathrm{m})\end{array}$ & 290 & 230 & 1060 & 1360 \\
\hline
\end{tabular}

プロセスで溶製された材料に比して, 介在物粒子数, 最大粒子の大きさともに大幅に低隇されていることが わかる.いま $2 \mu \mathrm{m}$ 以上の介在物粒子が供試材中に規 則的に配位されており, 粒子の中心位置が立方体格子 の頂点にあると仮定し, 隣接する粒子の中心間距離を 介在物粒子間の平均距離として求めると, 表 4 に示す ようになる。

\section{3. 試験片形状および試験方法}

疲労き裂伝ぱ機構の比較のため, コンパクトテンシ ヨン試験片を用いて長い貫通き裂の疲労き裂伝ぱ試験 を室温で行った。島津製作所製油圧サーボ試験機を用 いて, $R=0.1$ で $10 \mathrm{~Hz}$ の正弦波を負荷した. 応力拡大 係数範囲 $(\Delta K)=20 \mathrm{MPa} \cdot \mathrm{m}^{1 / 2}$ で予き裂を導入した後 に, $\Delta K$ 漸減試験により $\Delta K<20 \mathrm{MPa} \cdot \mathrm{m}^{1 / 2}$ の $\Delta K$ と 疲労き裂伝ぱ速度 $(d a / d N)$ の関係を求めた。 $\Delta K>20$ $\mathrm{MPa} \cdot \mathrm{m}^{1 / 2}$ の $\Delta K$ と $d a / d N$ の関係は, $\Delta P=$ 一定とし て求めた.き裂長さは東京衡機製クラックメータを使 用し, 交流電気ポテンシャル法により測定した。試験 中 $50 \mathrm{~Hz}$ で 1 5 A の定電流を流した。また, 適宜負荷 周波数を $0.2 \mathrm{~Hz}$ に落として電気ポテンシャル出力波 形を記録した。電流供給端子と電圧検出端子の取付位 置と交流電気ポテンシャル測定装置のブロックダイヤ グラムは図 1 に示すとおりである。また, 疲労き裂伝 ぱ試験中き裂先端から $2 \mathrm{~mm}$ の位置(図 1 参照)にひ ずみゲージを貼り付けて, 電気ポテンシャルの出力と ひずみゲージの出力の比較を行った. 
表面微小疲労き裂発生伝ぱ機構の比較のため, 三点 曲げ試験片を用いて疲労き裂発生伝ぱ試験を室温で行 った. 三点曲げ試験片は, 支点間距離 $40 \mathrm{~mm} \times$ 幅 5 $\mathrm{mm} \times$ 高さ $10 \mathrm{~mm}$ の形状で, 表面は加工変質層の除 去のために電解研磨の後に $1 \mu \mathrm{m}$ のダイヤモンドペー ストで研磨した。油圧サーボ試験機を用いて，R=0.1 で $10 \mathrm{~Hz}$ の正弦波を $\Delta P=$ 一定として負荷した. $\Delta P$ は試験片表面中央部で最大応力 $\sigma_{\max }$ が $0.2 \%$ 耐力の ほぽ $80 \%$ となる $\sigma_{\max }=960 \mathrm{MPa}$ をえた。試験途中 で適宜試験機を停止してき裂の光学顕微鏡写真を撮影 し，写真上でき裂長を測定した. ジグを介し負荷した 状態で写真撮影を行ったため, き裂が開口し, 先端が 明りょうに観察された。

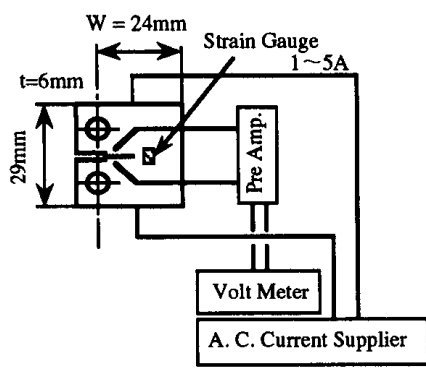

図 1 コンパクトテンション試験片と交流電気ポテンシャ ル測定装置の概要

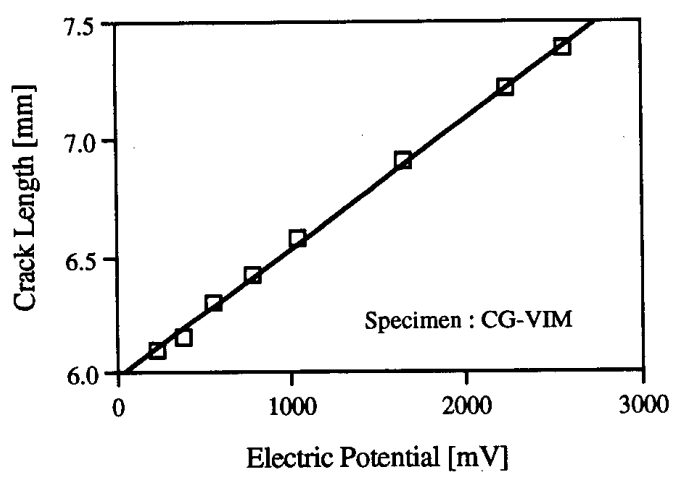

図 2 き裂長さと電気ポテンシャルの関係

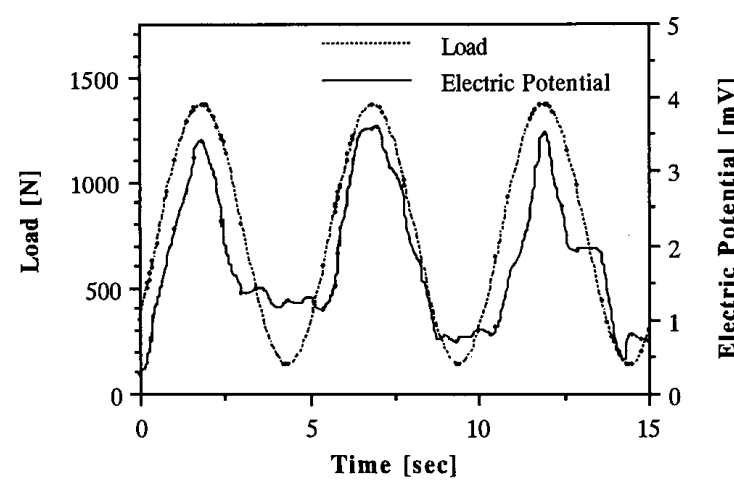

図 3 時間軸に対してプロットした電気ポテンシャルと荷 重の波形の例 $\left(\mathrm{CG}-\mathrm{VIM}\right.$ 材で $\left.\Delta K=9.8 \mathrm{MPa} \cdot \mathrm{m}^{1 / 2}\right)$

\section{4. 試 験 結 果}

$4 \cdot 1$ 長い貫通き裂の疲労き裂伝ぱ速度 図 2 に 示すように, コンパクトテンション試験片を用いた疲 労き裂伝ぱ速度の測定範囲内 $(0.2 \mathrm{~W}<a<0.7 \mathrm{~W})$ で は，き裂長さと電気ポテンシャルの直線関係が得られ た. 負荷サイクルに伴い電気ポテンシャル出力も軽微 な周期的変動を示すが, 平均荷重時の電気ポテンシャ ル出力をき裂長さと対応させた．図 3 に示すのは時間 軸に対してプロットした電気ポテンシャルと荷重の波 形の例であり, CG-VIM 材で $\Delta K=9.8 \mathrm{MPa} \cdot \mathrm{m}^{1 / 2}$ に て記録したものである. 最小荷重付近で電気ポテンシ ヤル波形が荷重波形に追従せずに停滞する部分が見ら れる。これは，最小荷重付近でのき裂の閉口によるも のと考えられる. 図 3 の結果について，電気ポテンシ ヤルを荷重に対してプロットしたものが図 4 である. き裂の開口に対応すると考えられる荷重 $\left(P_{\mathrm{op}}\right)$ とき裂 の閉口に対応すると考えられる荷重 $\left(P_{\mathrm{cl}}\right)$ はこの場合 ほぼ等しく, $P_{\mathrm{op}}=P_{\mathrm{cl}}$ である。図 5 はひずみゲージの 出力と荷重の関係の例を示すグラフである．図中の $\Delta K_{\text {eff }} / \Delta K$ は電気ポテンシャルと荷重の関係から求め た $P_{\mathrm{c} 1}$ を用いて算出したものである. $\Delta K_{\mathrm{eff}} / \Delta K$ の変化 に対応してひずみゲージの出力と荷重の関係に変化が みられる、電気ポテンシャルと荷重の関係から有効応 力拡大係数範囲 $\Delta K_{\text {eff }}$ を算出し, $\Delta K$ と $\Delta K_{\text {eff }}$ の関係

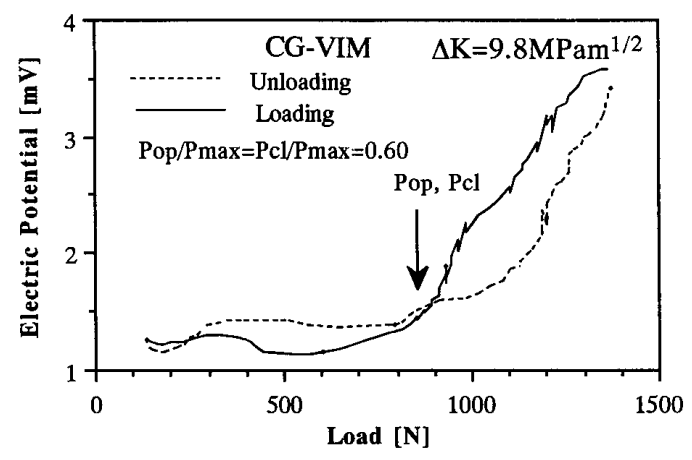

図 4 電気ポテンシャルと荷重の関係の例

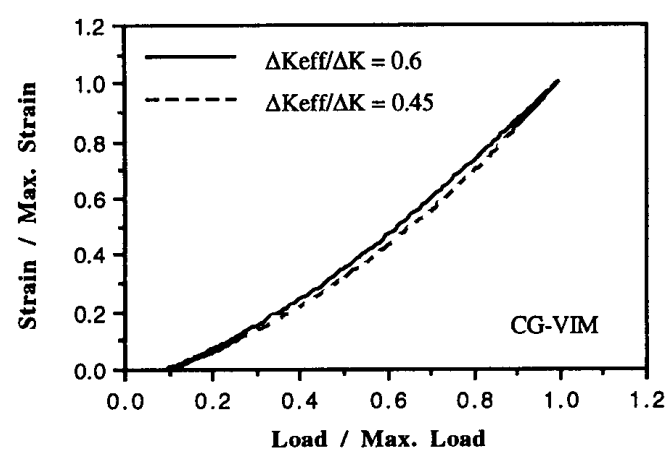

図 5 ひずみゲージの出力と荷重の関係 
を図6にまとめた。 FG-EB, FG-VAR おるび CG-EB はほとんど差はなく, CG-VIM が低い $\Delta K$, つまり $\Delta K_{\mathrm{th}}$ 近傍でよりに裂閉口の影響が大きいことがわか る.

実験から得られた長い貫通き裂の $\Delta K, \Delta K_{\text {eff }}$ と $d a / d N$ の関係を図 7 および図 8 に示す. 粗結晶粒材, 細結晶粒材ともに，清净度の高い $\mathrm{EB}$ 材のき裂伝ぱ速 度が高い傾向にある。また，EB 材同士の比較では，結 晶粒径によらず，ほほ同様な $\Delta K-d a / d N$ および $\Delta K_{\text {eff }}$ $d a / d N$ の関係が得られた。

コンパクトテンション試験片の破面観察の結果, 各 材料ともき裂開几10影響の大きくなる $\Delta K_{\mathrm{th}}$ 近傍では, き裂はすべり面に沿って伝ぱし，粗いファセット状の 外観を呈す. $\Delta K$ の増加に伴いファセット状破面率が 低下し, 平担なストライエーションを伴う破面が優勢 となる。図 $9(\mathrm{a})$ おょび(b)にそれぞれ $\Delta K_{\mathrm{th}}$ 近傍と $\Delta K=30 \mathrm{MPa} \cdot \mathrm{m}^{1 / 2}$ 付近での CG-EB 材の破面写真を 示す.また, 汹 $9(\mathrm{c})$ 扔よび (d) はそれぞれ $\Delta K_{\mathrm{th}}$ 近傍 と $\Delta K=30 \mathrm{MPa} \cdot \mathrm{m}^{1 / 2}$ 付近での CG-VIM の破面写真

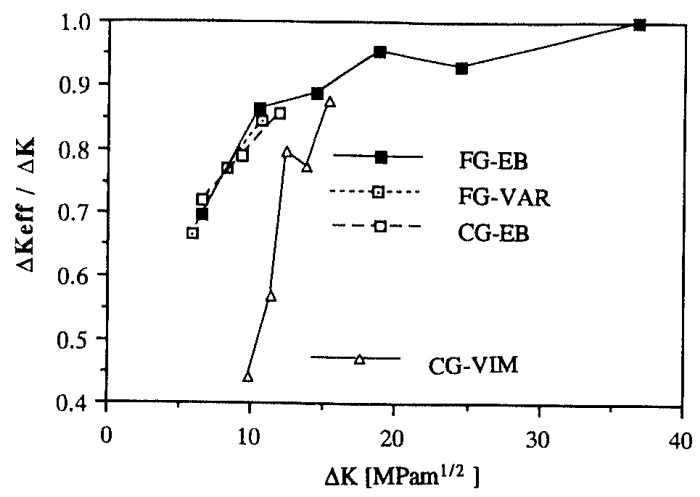

図 6 電気ポテンシャルと荷重の関係から求めた有効応力 昖大係数範明 $\Delta K_{\text {eff }}$ と $\Delta K$ の関係

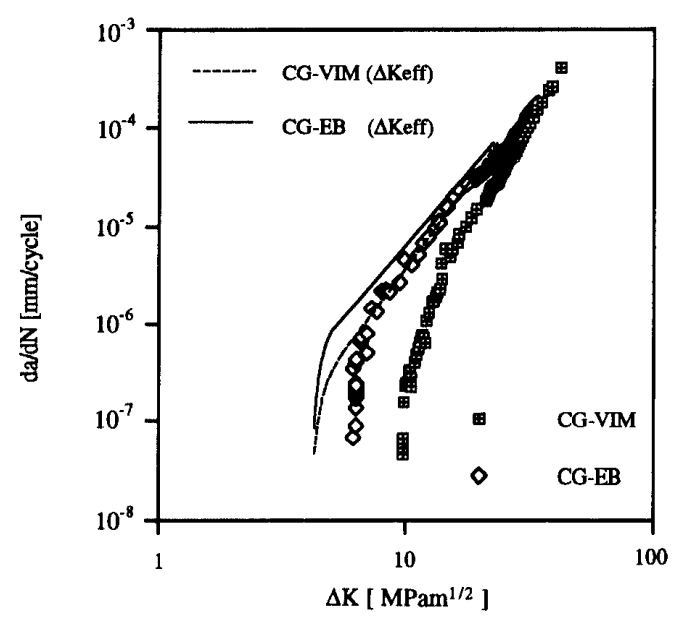

四 7 コンパクトテンション試験片を用いて求めた長い貫 通き裂の $\Delta K, \Delta K_{\mathrm{eff}}$ と $d a / d N$ の関係 (粗結晶粒材)
である。結晶粒径の大きな $\mathrm{CG}-\mathrm{VIM} の ~ \Delta K_{\mathrm{th}}$ 近傍では 特に粗い破面が形成されている. $\Delta K_{\mathrm{th}}$ 近傍でのき裂閉 口は，この破面の違い，すなわち，き裂伝ば機構の違 いに大きく依存するものと考えられる。疲労き裂先端 に形成される繰返し塑性域寸法 $r_{r p z}$ は平面応力状態 を仮定すると，次の式で表される(6).

$$
r_{r p z}=\frac{1}{\pi}\left(\frac{\Delta K}{2 \sigma_{y}}\right)^{2}
$$

ここで $R=0.1, \sigma_{y}$ を $0.2 \%$ 耐力に相当する 1100 $\mathrm{MPa}$ とし, $\Delta K$ をすべての材料でファセット状の破 面が観察される $\Delta K=10 \mathrm{MPa} \cdot \mathrm{m}^{1 / 2}$ とすると, $r_{r p z}=$ $6.6 \mu \mathrm{m}$ である. $r_{r p z}$ は平均結晶粒径よりも小さく, 結 晶粒界での転位の捕捉が生じにくい，き裂先端の結晶 粒のオリエンテーションによってはき裂先端を含む粒 の中の限られたすべり系しか作用せずに，あるすべり 帯に沿ったき裂伝ぱが生じ, 別のすべり帯に生じた割 れと連結することによって結晶粒断面がファセット状 に平担に破断したような破面が多く観察されるものと 考えられる．この場合，局所的にはき裂にモードI と モードIIの混成した負荷が働き，図 10 のモデル(7) に 示すような破面の粗さ，あるいはき裂の屈曲に起因し たき裂閉口が生じやすくなるものと考えられる，最も 結晶粒径の大きいCG-VIM 材で特に破面が粗かった ため, このモードIIの負荷と破面粗さ誘起のき裂閉口 が顕著に現れ，低 $\Delta K$ の領域での $\Delta K_{\mathrm{eff}}$ の著しい減少 により $\Delta K_{\mathrm{th}}$ が他の材料よりも高くなったと考えられ る. $\Delta K$ の増加に伴い平担なストライエーションを伴 う破面が優勢となると，このようなモードII の負荷と 破面の屈曲に起因したき裂閉口は起きにくくなる。

$4 \cdot 2$ 表面微小疲労き裂の伝ぱ速度 図 $11 に$, 各

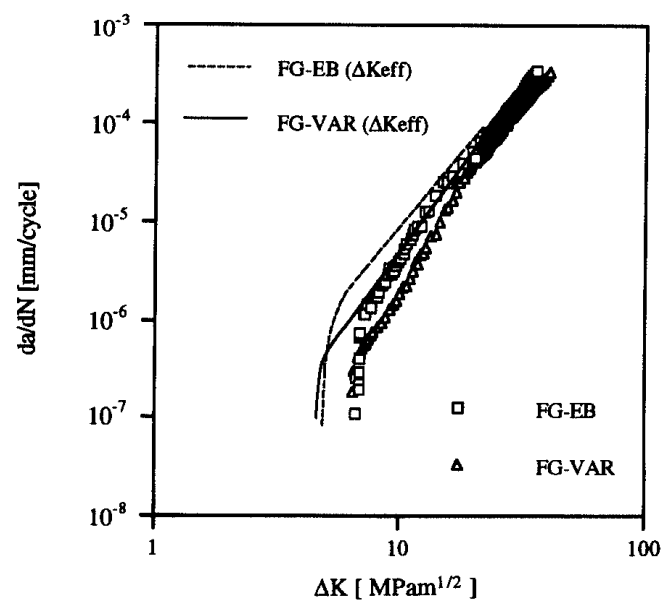

図 8 コンパクトテンション試験片を用いて求めた長い貫 通き裂の $\Delta K, \Delta K_{\mathrm{eff}}$ と $d a / d N$ の関係 (細結晶粒材) 
材料中で観察された表面微小き裂のうち, 最も早く発 生, 伝ぱしたもののき裂長さと負荷の繰返し数の関係 を示す。細結晶粒材のほうが表面微小き裂の発生と伝 ぱにより長い時間を費やし, 高清浄度化によりさらに 表面微小き裂の発生と伝ぱに要する時間が延長され る. 本試験では, き裂発生の起点は, 図 $12(\mathrm{a})$ および (b)に示すように, 介在物を起点とするものと, すべ り帯から成長するものに大別された。

図 13 および図 14 にそれぞれ粗結晶粒材と細結晶粒 材の $\Delta K$ と $d a / d N$ の関係を長い貫通き裂の結果とと もに示す。観察の結果, 表面き裂はほぼ半円き裂とみ なせるため, $K$ 值の算出に当たっては, 試験片表面の き裂先端における $K$ 值をNewmanらの式(8)を用い て算出した，図から明らかなように，いずれの場合も 微小き裂が長大化するに従い長い貫通き裂の結果に近 づいてくる.また, 結晶が細かく, 清浄度の高いものほ ど, 低い伝ぱ速度を示す。

また，表面微小き裂は $\Delta K_{\mathrm{th}}$ 近傍で長い貫通き裂に 比べて極めて高速に伝ぱする. $\Delta K_{\mathrm{th}}$ 近傍では表面微小

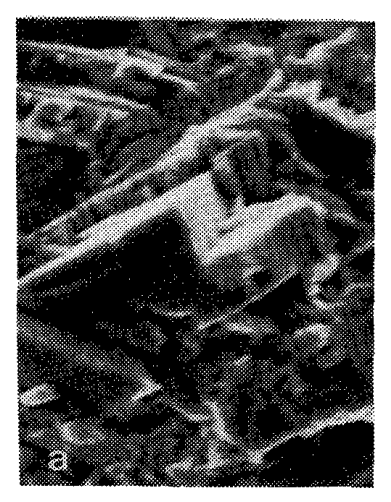

$5 \mu \mathrm{m}$

(a) $\mathrm{CG}-\mathrm{EB} の \Delta K_{\mathrm{th}}$ の近傍

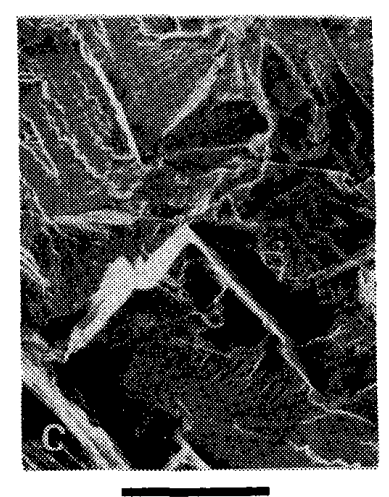

$20 \mu \mathrm{m}$

(c) $\mathrm{CG}-\mathrm{VIM} の \Delta K_{\mathrm{th}}$ 近傍

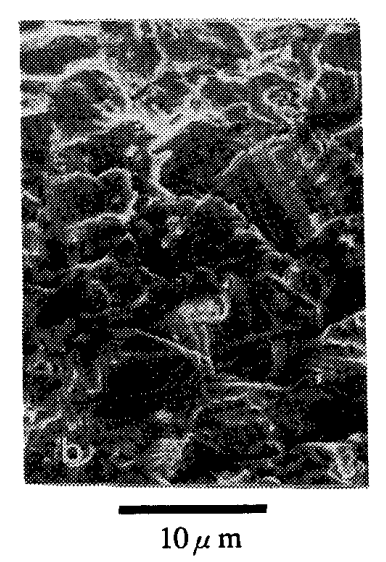

(b) $\mathrm{CG}-\mathrm{EB} の \Delta K=30$ $\mathrm{MPa} \cdot \mathrm{m}^{1 / 2}$ 付近

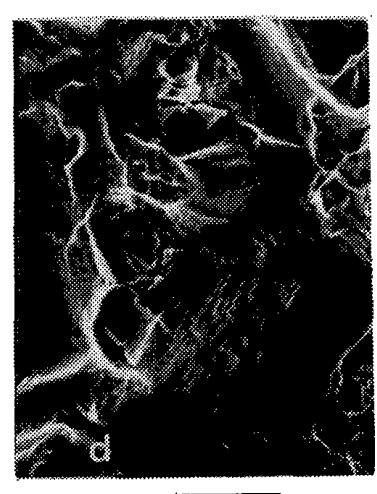

$20 \mu \mathrm{m}$

(d) $\mathrm{CG}$-VIM の $\Delta K=30$ $\mathrm{MPa} \cdot \mathrm{m}^{1 / 2}$ 付近
き裂, 長い貫通き裂ともにファセット状の破面を呈し, すべり帯に沿ったき裂伝ぱが生じている.しかし，表 面微小き裂ではき裂長さがきわめて短く, 図 10 のモ デルに示すようなき裂の屈曲とモデル II の負荷に起因 したき裂閉口は起きにくく, 長い貫通き裂に比べて大 きな $\Delta K_{\mathrm{eff}}$ が得られていることが, 高速き裂伝ぱの原 因のひとつであると考えられる.図 15 は CG-VIM 中 を最も速く伝ぱした表面微小き裂の開閉口挙動の電気 ポテンシャルによる測定の結果を, 長い貫通き裂の結 果と比較したものである. CG-VIM 中の長い貫通き裂 では $\Delta K_{\mathrm{th}}$ 近傍でき裂閉口が顕著であるのに対して,
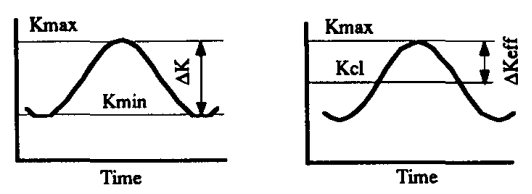

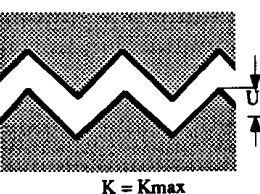

（a）最大荷重

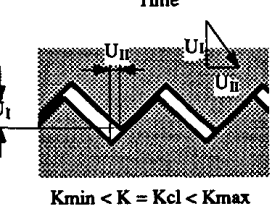

（b）最小荷重
図 10 き裂の屈曲に起因したき裂閉口のモデル

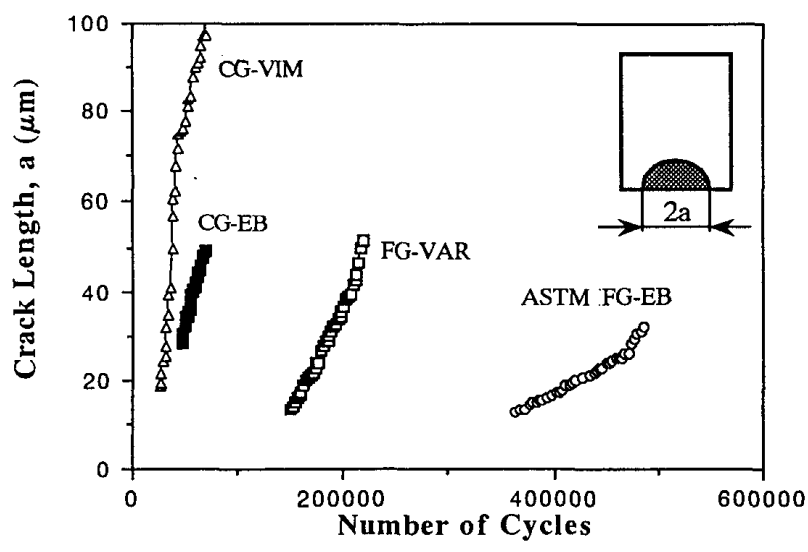

図 11 表面微小き裂の長さと繰返し数

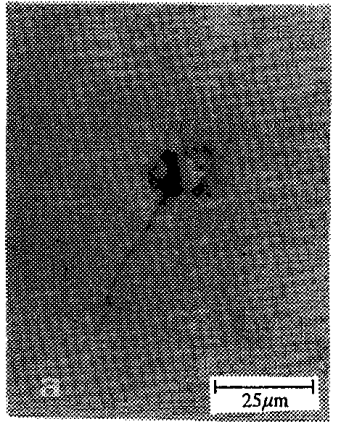

(a) CG-VIM材で介在物を 起点としたき裂

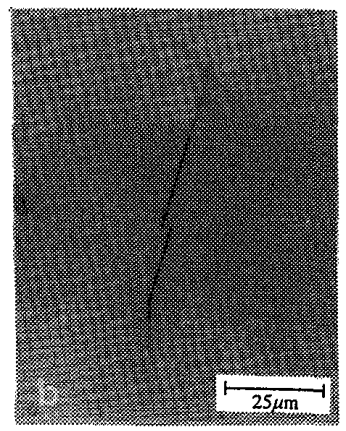

(b) CG-EB 材ですべり帯 から発生したき裂
図 9 コンパクトテンション試験片破面 
表面微小き裂では同程度の $\Delta K$ ではずっと低い荷重 レベルで $P_{\mathrm{cl}}$ が現れている.

長い貫通き裂では結晶粒径の大きなものが $\Delta K$ で 整理した場合に低い伝ぱ速度を示したのとは反対に， 微小き裂では結晶粒径の大きなものが高い伝ば速度を 示した.長い買通き裂の場合，低 $\Delta K$ 領域でき裂先端の 塑性域寸法が二次元的に平均結晶粒径に比べて小さく ても,コンパクトテンション試験片の板厚を考えれば 塑性域の中に必ず結晶粒界が多数存在しており，き裂 は粒界の抵抗を受けながら進むのに対し，微小き裂は 三次元的に微小であり，き裂先端の塑性域全体が 1 個 から数個の結晶の非に入ってしまう.前報(3)で示したよ うに微小き裂は粒界の抵抗を受けずに粒内を進むとき には極めて高速であり，結晶粒径が大きいほど粒界の 抵抗を受けずに長い距離を伝ぱできるため，粗結晶粒 材では微小き裂の伝ぱ速度が高くなるものと考える。

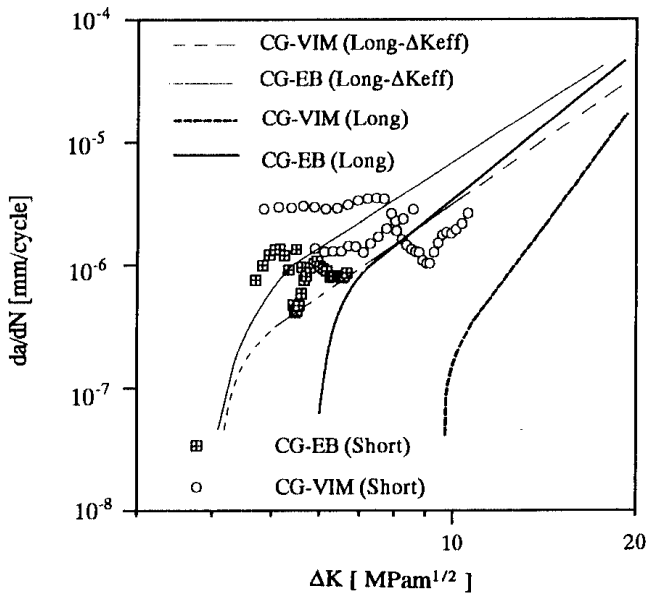

图 13 粗結鼎粉材中の表面微小き裂の $\Delta K$ と $d a / d N$ の 関係

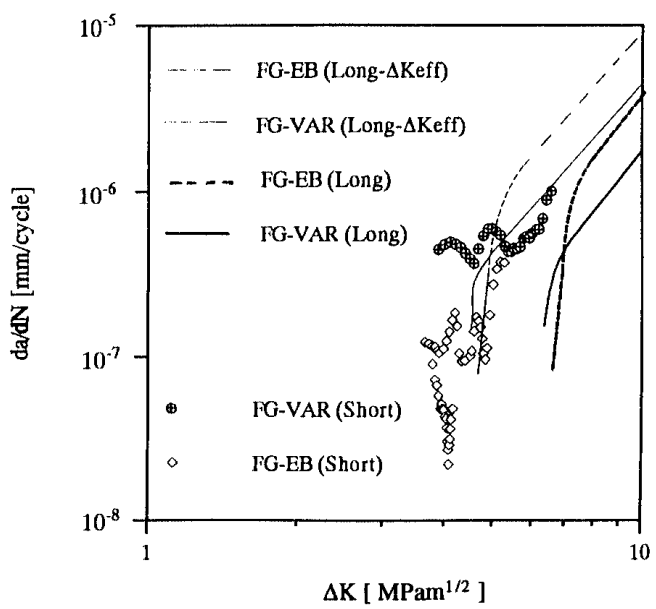

図 14 細絬蜫粒材帄の表百微小き裂の $\Delta K$ と $d a / d N$ の 関係

\section{5. 清浄度の影響について}

表 2 に示されたように，高清浄度の EB 材は引張強 度が高く破断伸びが低い傾向にあるが, 電子ビーム溶 解では溶製過程で介在物粒子を除去することが核生成 因子の低減につながり，凝固過程でより微細で多数の 炭化物が析出するという副次的効果があること(9), ま た，ガス成分， $\mathrm{Mg}$ 等の微量元素が溶製過程で揮発除 去されたことにより粒界, マトリックスの清浄度が高 くなり，機械的強度に影響を与えていることなどが寄 与していると考えられる。このことを詳しく調べるた めに, 種々の結晶粒徍の材料について行ったビッカー ス硬さ試験の結果を図 16 に示す.す心゙ての材料には同 じ標準的時効処理を施した. 図に示された各点は試料 上で無作為に選んだ 10 から 20 の測定点での測定值の 平均值である.ビッカース硬度の粒径依存性が認めら れる。また，明らかに電子ビーム溶解した材料が低い 硬度を示している.ビッカース硬さは一般的に引張強 度と正の相関があるものと考えられるから，この結果 は表 2 に示された引張試験の結果と一見矛盾するよう に感じられる.次に, 清浄度の上で最も差の大きなFG$\mathrm{EB}$ と FG-VARについて, マイクロビッカース試験 機を用いて求めた粒界と粒内の硬さを図 17 に示す.各 点は 10 から 20 の測定点での測定值の平均值である. 結晶粒径の影響を除くために平均結晶粒径 $200 \mu \mathrm{m} の$ 試料を用い，また，時効硬化の影響を除いてマトリッ クスの清浄度の影響がよくわかるように, 溶体化処理 のみを施した.図 16 に示した巨視的な硬さのデータと 同様に，電子ビーム溶解材は全般的に軟らかい. FGVARでみられる粒界の硬さと粒内の硬さの差に比べ て, FG-EBでは粒界と粒内でより大きな硬さの差が 生じていることが特徴的である。結晶粒界は単にオリ

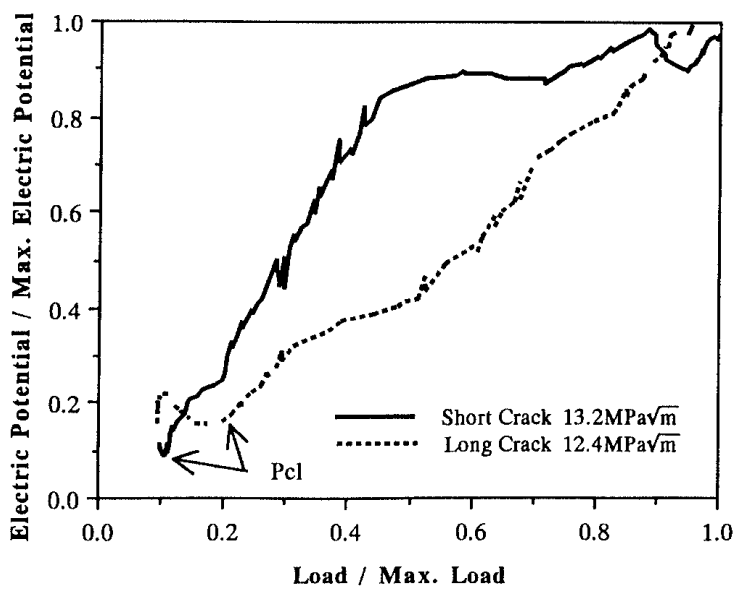

図 15 表面微小き裂と長い貫通き裂の開閉口挙動の比較 
エンテーションを異にする結晶粒の境界面であるので はなく，炭化物や微量元素の偏在するある幅を持った 領域と考えられるが, 圧痕の大きさに比べれば極めて 幅が狭い，したがって，ここで粒界の硬さと言ってい るのは，正確には粒界を含む領域の硬さである。

さて，多結晶金属の降伏応力は，材料固有の内部抵 抗(単結晶の強さ)，粒界の強化機構および結晶粒径に 影響を受けるものでありこのことは次のように Petchの式で表現されている.

$$
\sigma_{y s}=\sigma_{0}+k \cdot D^{-1 / 2}
$$

ここで， $\sigma_{y s}$ は降伏応力， $\sigma_{0}$ は材料固有の内部抵抗， $k$ は粒界の強化機樍に依存する定数, $D$ は結晶粒径で ある. 電子ビーム溶解した高清浄度材で粒内の硬さが 低いことから，上式において $\sigma_{0}$ が低いことが予想さ れる。しかし，同程度の結晶粒径のもので比較して高 清浄度材の $\sigma_{y s}$ が低くなっていないこと, FG-EB で 粒界と粒内で大きな硬さの差が生じていることから， 粒界の強化機構に依存する定数 $k$ 峐清浄度材で高 くなっているものと考えられる．凝固過程で析出した より微細で多数の炭化物 ${ }^{(9)}$ が高清浄度材の粒界強化 の主たる要因と考えられる。

本試験で得られた長い貫通き裂の $\Delta K$ と $d a / d N$ の 関係で, 細結晶粒材が高い伝ぱ速度を示すことは，他 のニッケル基合金の試験結果 ${ }^{(10)}$ とも一致する. 清浄度 が高くなると, 細結晶粒化と同様に, 伝ぱ速度を高め る効果がある。しかし，き裂閉口の影響を除いて $\Delta K_{\mathrm{eff}}$ で整理すると長い貫通き裂の伝ぱ速度の差は数倍以内 のものである.

微小き裂においては $\Delta K=5 \mathrm{MPa} \cdot \mathrm{m}^{1 / 2}$ 付近では最 高速の CG-VIM と最低速の FG-EB の間には数十倍 以上に達する伝ぱ速度の差を生じた。FG-EB は同じ 細結晶粒の FG-VAR と比較しても顕著に低速であ

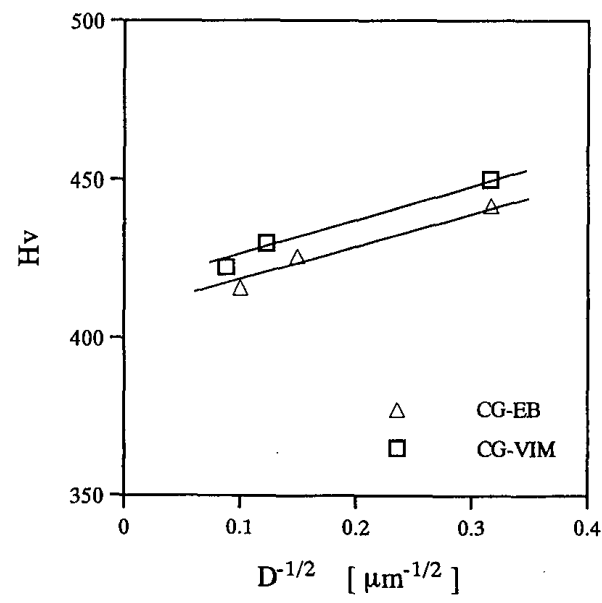

図 16 CG-VIM とCG-EB のビッカース硬さの比較
る. 高清净度のものが低い伝ぱ速度を示したが, 清净 度が微小き裂の伝ぱ速度に及ぼす影響を考えるとき， 表 4 に示したように介在物粒子間の距離は結晶粒径や き裂先端の塑性域寸法に比べてはるかに大きいため， 介在物に起因した応力集中や, 介在物とマトリックス の境界はく離による強度の低下といった, 介在物の存 在そのものにより引き起こされる事象が支配的な問題 と考えることはできない.やはり，マイクロビッカー ス試験で確認された, 清浄度の違いによる粒内と粒界 の強化の機構の差が大きく影響しているものと考えら れる.き裂先端の塑性域の大きさが結晶粒径と同程度 か小さい微小き裂においては限られた方向のすべり系 のみが作動しやすく，同一のすべり面上での Reverse Slipp ${ }^{(11)}$ が生じやすいと考えられるが, 侵入形元素とし てあるいは介在物形成元素として結晶格子をひずませ る不純物ガス成分が少ないために粒内の抵抗が少ない 電子ビーム溶解した高清浄度材ではさらに Reverse Slip が生じやすいと考えられる．結果として高清浄度 材でき裂伝ぱ速度が低下しているものと考える.

表面微小き裂の発生に対しては介在物の存在は大き な影響がある。図 12 (a)に例を示したように，表面微 小き裂は介在物を起点として発生する場合がある。本 試験のような曲げ試験では，試験片表面で応力が最大 となる位置, すなわち, 微小き裂の発生の確率が最も 高い位置が限定されてしまうが，平滑な試験片に軸方 向に負荷を与える疲労試験の場合には，介在物を起点 として疲労き裂が発生, 伝ぱする確率が高くなる。著 者らが FG-VAR の丸棒形試験片を用いて行った寿命 が $10^{4}$ から $10^{6}$ サイクル程度となる疲労試験(1)では, ほとんどすべての場合疲労き裂の起点は表面近くの介 在物であり，繰返し荷重の負荷が始まるとすぐに起点 の介在物からき裂の伝ぱが始まるとみなせた。また，

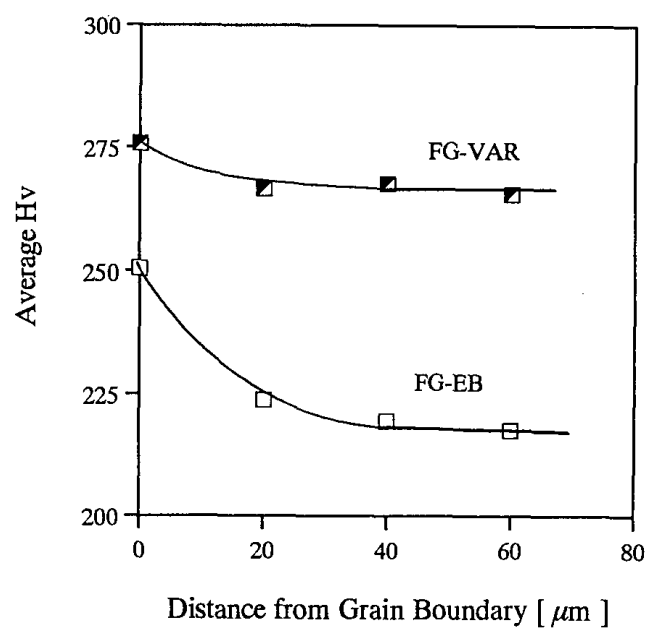

図 17 FG-VAR と FG-EB の粒界と粒内の硬さの差 
寿命の大半は微小き裂の伝ぱ期間であった。ひとたび 介在物から表泊微小き裂が発生伝ぱを始めると, 介在 物の大きさが技等寿命に少なからぬ影響を与えること は容易に想像できる。もし，同じ材料で作られたふた つの北験片で，大きさの違う介在物を起点として同時 に疲学き裂が伝ぱを開始したとすると，介在物の大き さを初期さ裂長さと考えれば，初期き裂長さの差分を き裂が伝ぱするのに要する時間だけ，疲労寿命に差が 生じることになる。例えば，図 11 の表面微小き裂の長 さと結返し数の関係から $10 \mu \mathrm{m}$ のき裂が $50 \mu \mathrm{m}$ に成 長するまでの継汶し数は，FG VARでは $1 \times 10^{5}$ サイ クルにも及ぶものである。したがって, 非金属介在物 の量と大きさの低減は，表面微小き裂の発生と伝ぱを 妨げる効果がある。

清浄度の高いものほど低い表面微小き裂の伝ば速度 を示すこと, $10^{4}$ から $10^{6}$ サイクルの寿命となる疲労 試験では寿命の大半は微小き裂の伝ば期間であるこ と、ひとたび介件から表面微小き裂が発生伝ぱを始 めると, 起点の介在物の大きさが表面微小き裂の伝ぱ 期間に影響を及低すことから，平滑材の表面あるいは 表面近傍の介在物等の欠陷から微小き裂が発生して巨 視的なき裂へと成長し $K_{\max }$ が一定值に達したときに 材料が破堎するとすれば，高清浄度化によるニッケル 基合金の疲労玤命の延長は，表面微小き裂の伝ぱ速度 の差と起点となる欠陮の大きさの差により, 高清浄度 材で表面微小き裂の伝ぱ期間が延長されることによる ものと考えることができる。

\section{6. 結訔}

本研究では, 電子ビームコールドハース溶解した高 清浄度のIN 718 と従来プロセスで溶製された IN 718 を用いて波学き裂伝ぱ試験を行い, 疲労き裂伝は機構 に及ぼす清浄度の影響を調べた。得られた知見は次の とおりである。

（1）コンパクトテンション試験片を用いた長い貫 通き裂の伝ぱ速度試験では，各材料ともき裂閉口の影 響の大きくなる $\Delta K_{\mathrm{th}}$ 近傍では，き裂はすべり面に沿 って伝ぱし，破俑はファセット状である。き裂閉口の 影響の最も大きかった CG-VIM で最も大きなファセ ットが観祭された。 $\Delta K$ の增加に伴いファセット状破 面率が低下し，斗㫮なトライエーションを伴う破面 が優勢となり，き裂閉凹が起こりにくくなる。

（2）粗結旨粒材，細結晶粒材ともに，清浄度の高 いEB 材の長い買通き裂伝ぱ速度が従来材に比べて高
い傾向にある。また，EB材同士の比較では，結晶粒径 によらず，ほぼ同様な $\Delta K-d a / d N, \Delta K_{\mathrm{eff}}-d a / d N$ の関 係が得られた。き裂閉口の影響を除いて $\Delta K_{\mathrm{eff}}$ で整理 すると, 結晶粒径と清浄度の違いによる長い賁通き裂 の伝ぱ速度の差は数倍以内のものである.

（3）長い貫通き裂の挙動とは対照的に，表面微小 き裂では清净度の高い $\mathrm{EB}$ 材が従来材に比べて低い伝 ば速度を示す。

（4）表面微小き裂は $\Delta K_{\mathrm{th}}$ 近傍で長い貫通き裂に 比べて極めて高速に伝ぱする. $\Delta K_{\mathrm{th}}$ 近傍では表面微小 き裂，長い貫通き裂ともにファセット状の破面を呈し， すべり帯に沿ったき裂伝ばが生じている．表面微小き 裂ではき裂長さが極めて短くき裂の屈曲とモード II の 負荷に起因したき裂閉口は起きにくく，長い貫通き裂 に比べて大きな $\Delta K_{\text {eff }}$ が得られていると考えられる。 結晶粒径と清浄度の違いによる表面微小き裂の伝ぱ速 度の差は極めて大きく, $\Delta K=5 \mathrm{MPa} \cdot \mathrm{m}^{1 / 2}$ 付近では最 高速の CG-VIM と最低速の FG-EBの間には数十倍 以上に達する伝ば速度の差を生じた。 FG-EB は同じ 細結晶粒の FG-VAR と比較しても顕著に低速であ る。

（5） $10^{4}$ から $10^{6}$ サイクルの寿命となる疲労試験 で平滑材の表面あるいは表面近傍の介在物等の欠陥か ら微小き裂が発生して巨視的なき裂へと成長し $K_{\max }$ が一定值に達したときに材料が破壊するとすれば，高 清浄度化によるニッケル基合金の疲労寿命の延長は， 表面微小き裂の伝ぱ速度の差と起点となる欠楩の大き さの差により, 高清浄度材で表面微小き裂の伝ぱ期間 が延長されることによるものと考えることができる.

\section{文献}

(1) Denda, T., 任か 2 名, Met. Trans., A, 23(1992), 519.

(2) Koenig, R. J., Electron Beam Melting and Refining, (1991), 14.

(3) 傳田・ほか 3 名, 機論, 60-576, A (1994), 1746.

(4) Quested, P.N., ほか I 名, Electron Beam Melting and Refining, (1989), 10.

（5）出川，溶融金属中における非金属介在物の挙動解析と分 離技術, 日本金属学会, (1992), 17.

(6) Rice, J. R., Fatigue Crack Propagation, ASTM STP 415(1967), 247.

(7) Tien, J.K., Superalloys, Superceramics and Supercomposites, (1989), 396, Academic Press.

(8) Murakami, Y., Stress Intensity Factors Handbook, 2 (1987), 712.

(9) Hartmann, D., ほか 1 名, Electron Beam Melting and Refining, (1991), 211.

(10) Brown, C. W., 注加 1 名, Met. Sci., 18(1984), 347.

(11) Lasalmonie, ほか 1名, J. Mater. Sci., 21(1986), 1837. 